\title{
Siberia: in Search of New Model of Development
}

\author{
Alexander N. Pilyasov* \\ Center for the Arctic and Northern economies \\ under the ANO "Institute of regional consulting" \\ 17B Butlerov Str., Moscow, 117342, Russia
}

Received 24.07.2017, received in revised form 05.11.2017, accepted 13.11.2017

There is no other major macro-region of Russia, for which finding a new model of development would be as urgent and imperative as for Siberia. Being the leader in the country and the world in terms of natural resources and water resources, this treasury of natural resources still loses to other regions in the quality of life and living standards. The main development guideline for Siberia is openness to experiments and innovative search, which now involves the main constructive effects of the arrangement of Siberian spaces, rejection of unified approaches and a brand new role of the state to encourage innovations of all kinds and get away from its former role of a simple lobbyist for large corporations, working in Siberia.

The new development model of Siberia should take into account the following facts:

1. The most profitable industry for Siberia is not mining; it is processing industry, less sensitive to the ultracontinental character and isolation of the Siberian economy. Hybridity, the mixed nature of the new Siberian deposits, often makes it more reasonable to extract and process resources at the same place.

2. Flashbacks have always been typical of the economic development of Siberia: after a quick breakthrough there is a delay, a pause, which actually brings assimilation and consolidation of the innovation in the spaces of Siberia, followed by a new progressive step.

3. During active development periods, latitudinal communication along the routes and latitudinal transport channels dominate, and during the development pause (compression of development) "natural" (physical-geographical) communication along the basins of the great Siberian rivers takes over.

4. The means of rapid communication in Siberia are all subtended, which means absolute information periphery, a very slow exchange of ideas and, as a result, considerable intellectual conservatism. Special efforts should be made, specifically for Siberia, to ensure greater involvement in national and international information exchanges.

5. In terms of farming activity and rural telephone network coverage, Siberian village is relatively better prepared to absorb innovations, to update the model of economic development than an average Russian village, or villages of other federal districts.

6. The comparative role of large Siberian cities in the development of Siberia is certainly higher than that of urban agglomerations in other federal districts, precisely because of the low density and development level of Siberian spaces. In contrast to central areas, Siberian urbanization does not

(C) Siberian Federal University. All rights reserved

* Corresponding author E-mail address: pelyasov@mail.ru 
capture space entirely, but does it intermittently, selectively, through a network of outposts and local bases of development, which control the local, regional or wider regional space.

7. Just like creative people from all over the country accumulate in the creative regions of central Russia, talents from the colossal regional space are concentrated in the city centres of the vast Siberian territories. A special Siberian model of creativity once again confirms that Siberia should not aspire for the success of the Silicon Valley model, based on considerable communication density of the area. Here the innovation process models will be different, considering the isolation and periphery factors of the vast Siberian spaces.

8. The idea of increasing returns means obtaining effects from large and very dispersed urban agglomerations; economic regions that form localized sites of local economic clusters; contact territories of the Siberian Russian-Chinese borderland. All these effects involve the forces of small and medium-sized businesses, which generates them, actively interacting with each other and large resource companies in Siberia.

9. In contrast with the Soviet development of Siberia based on a system of stationary bases and development routes, new development of Siberia will be based on "light" vehicles and mobile means of energy supply that often do not require any fundamental infrastructural arrangement.

Keywords: Siberia, a new model of development, innovative development, increasing returns.

DOI: 10.17516/1997-1370-0171.

Research area: economics.

\section{Introduction}

There is no other major macro-region of Russia, for which finding a new model of development would be as urgent and imperative as for Siberia. There is no other place where the contrast between the glorious, legendary, even heroic past of the USSR-wide construction and other super-projects of the last quarter of the $20^{\text {th }}$ century, and the humble past and not quite definite future economic development would be that dramatic. For this reason the question of Siberian prospects and outlines of its future is topical not only in Siberia. It is a real intellectual challenge for experts from all over the country, and an imperative order to all regional consulting experts of Russia. This paper is an attempt to look at Siberian development through the eyes of an external expert with a hope that some issues, well-known to my colleagues from the research centres of Krasnoyarsk, Novosibirsk, Tomsk, Irkutsk, Omsk, and not being topics for scientific discussions, could be raised in a different way (shaping up the idea of new development pattern of Siberia).

\section{Old Siberia reclamation pattern has run its course}

Another obvious fact acknowledged by the majority of experts engaged in the development of Siberia is the impossibility to rely on the previous late-Soviet principles and approaches to the development of this macro-region. As it has been rightfully remarked by my colleagues from Irkutsk School of Economics and Geography, in the latest fundamental monograph on Siberian development, this treasury of natural resources, being the leader in the country and the whole world in terms of natural richness and water resources, loses to many federal districts in quality of life and living standards ${ }^{1}$. Siberia is rapidly losing its positions in the key economic criteria: the comparison of indices of the years 1998 and 2015 proves that the region is left behind the average national level (Table 1). It is a really fast process. For instance, it took only ten years for Siberia to fall from the $5^{\text {th }}$ to the $7^{\text {th }}$ position in the federal districts' rating in per capita income (Table 2). 
Table 1. Economic performance of Siberian federal district, per cent, in the Russian Federation

\begin{tabular}{|l|c|c|}
\hline & 1998 & 2015 \\
\hline Territory & 30.0 & 30.0 \\
\hline Population & 14.3 & $13.2(1.01 .2016)$ \\
\hline GRP & 13.9 & $10.4(2014)$ \\
\hline Industrial products & 14.0 & 11,6 \\
\hline Agricultural products & 16.6 & 12.2 \\
\hline Fixed investment & 10.3 & 9.5 \\
\hline Retail turnover & 11.7 & 10.0 \\
\hline Tax revenue into the RF budget system & 10.8 & 8.9 \\
\hline Export & 12.4 & 8.8 \\
\hline Import & 7.4 & 3.8 \\
\hline
\end{tabular}

Data for the year 1998 adopted from the monograph "State and territorial structure of Russia (economic and legal basis)". Executive editor A.G. Granberg, V.V. Kistanov. Moscow: DEKA. 2003. 448 p. P. 382; for the year 2015, official Russian Federal State Statistics Service data is quoted

Table 2. Monthly per capita income, in roubles

\begin{tabular}{|l|c|c|c|c|}
\hline & 2005 & 2010 & 2015 & $\begin{array}{c}\text { Position in the Russian } \\
\text { Federation, 2015 }\end{array}$ \\
\hline Russian Federation & 8088 & 18958 & 30474 & 1 \\
\hline Central Federal District & 10902 & 24645 & 38776 & 2 \\
\hline Far Eastern Federal District & 8989 & 20807 & 36320 & 3 \\
\hline Ural Federal District & 9581 & 21832 & 32794 & 4 \\
\hline Northwestern Federal District & 8996 & 19837 & 32388 & 5 \\
\hline Southern Federal District & 5757 & 15114 & 27004 & 6 \\
\hline Volga Federal District & 6229 & 15840 & 26300 & 7 \\
\hline Siberian Federal District & 6731 & 15007 & 23584 & 8 \\
\hline North Caucasian Federal District & 4537 & 13253 & 23023 & 9 \\
\hline Crimean Federal District & & & 16063 & \\
\hline
\end{tabular}

From: Russian Federal State Statistic Service

There is no other federal district, where the gap between the resource and spatial potential, between the privileged positions in the "primary" resource performance, the performance in primary resource processing, and the "terminal", integral social and economic performance would be just as big as in Siberia (Table 3). This contrast is typical of Russia as a whole, if compared to other countries listed in the top-twenty in the gross national product. In this regard we can say that the underlying economic contrasts of the largest Russian macro-region are projected on the country as a whole. But it means, that, without the key to the current development of Siberia, we cannot hope for handling the other large national social and economic contrasts and contradictions (so rich, but so poor).

During the Soviet era, Siberia used to get much more for its social and economic development in return for the resources it provided to the state than it does now. The contemporary resource corporations appeared not to be ready to take the obligations the state trusts and management boards used to accept 
Table 3. Position of Siberian Federal District among other federal districts in 2015

\begin{tabular}{|c|c|}
\hline & SFD rating \\
\hline \multicolumn{2}{|l|}{ "Primary" resource and raw materials } \\
\hline Forest areas, $\%$ & 1 \\
\hline Total timber resources, million $\mathrm{m}^{3}$ & 1 \\
\hline Lumber production, thousand $\mathrm{m}^{3}$ & 1 \\
\hline Electric power production (billion $\mathrm{kWh}$ ) & 2 \\
\hline Agricultural area, thousand ha & 1 \\
\hline Gross yield of flax fibre, thousand tons & 1 \\
\hline $\begin{array}{l}\text { Production of flour of grain, vegetables and other plant crops and flour mixes } \\
\text { (thousand tons) }\end{array}$ & 2 \\
\hline Cereal production (thousand tons) & 2 \\
\hline Stock of cattle, thousand per year & 2 \\
\hline \multicolumn{2}{|l|}{ Result performance } \\
\hline Life expectancy at birth, years & 8 (of 9) \\
\hline Income per capita, roubles & 7 \\
\hline Consumer expenditures per capita, roubles & 8 \\
\hline Retail turnover per capita, roubles & 8 \\
\hline Commercial services per capita, roubles & 8 \\
\hline Domestic services per capita & 9 \\
\hline Transportation services per capita & 8 \\
\hline Recorded crimes per 100 thousand people & $\begin{array}{l}1 \text { (the worst, the positions } \\
\text { lost in the last years) }\end{array}$ \\
\hline
\end{tabular}

From: Russian Federal State Statistic Service

(and which were considered to be absolutely insufficient at that time). So, the old development model does not work anymore, while the new one, adjusted for the essential peculiarities of Siberian economy, has not emerged yet.

Siberian paradox claims that the richer in resources a territory is, the poorer it happens to be. Where is the "withdrawal" that drops the rating of Siberia so dramatically at the transition from the resource potential to assets and yields? The obvious conclusion can be formulated as follows: around a quarter of century ago, Siberia turned out to be less prepared for the sharp turn to denationalization and corporatization of its basic natural assets and infrastructural systems, than any other macro-region of the country. The adjustment to the new situation has been long and terribly painful. A new economic model of development that would hold its positions (even if at a lower level than it used to be during the Soviet times) among other Russian federal districts, has not been suggested yet.

\section{Myths of basic peculiarities of Siberian economy}

Here arises a natural question: what are the fundamental peculiarities of Siberian economy, that were so efficiently considered and used in the late Soviet period and that still fail to be applied for any positive, not negative result? All these peculiarities are tightly connected to the presence of colossal, but scarcely populated and lowdensity spaces, that shape up an unprecedented situation for the global territorial management 
practice $^{2}$. This question is especially relevant, because it yields more myths, distorted and often wrong perceptions, than any other.

The triad of essential peculiarities of Siberian economy consists of: ultracontinental nature, corporativity, zonality. There is no other federal district in Russia which had these features as emphasized as Siberia. And, of course, there is no other federal district where this trinity would manifest itself in such systematic integrity and totality as in Siberia.

Myth 1. Due to its ultracontinental location, remote from the main navigation routes and external markets, Siberia is an internal colony of Russia. The concept of ultracontinental nature of Siberia was first formulated by a famous economist and geographer from Irkutsk, L.A. Bezrukov ${ }^{3}$. Rewording one famous song, Siberia is a sea of taiga, but it is taiga without sea. For real, in terms of remoteness from the main navigation routes, Siberia is a macro-region with an unprecedented "overland" economic and geographic position both in Russia and the world as a whole. The overland nature of Siberia means colossal transportation expenses, and incredible economic friction in travelling through the distances to break into any large national or international markets. This is why transport and transportation systems (and, indeed, transport fees as a Siberian economic super-institution ${ }^{4}$ ) play an absolutely unique role in Siberia, knitted together with the functioning of production systems to such an extent that it makes sense to introduce a notion of "production and transport system" that formed a basis of the first Siberian territorial industrial facilities of the Soviet period.

But here arises another important methodological question: is it logical to draw a thesis on the colonial character of Siberian economy from the fact of its ultracontinental character? Of course, it is not!
Being a colony means being in the periphery, while Siberia is the very middle of Russia! Being a colony means having maritime communications with the mother country, while Siberia enjoys the Trans-Siberian railway and multiple overland connections. Colonial super-organizations of Hudson Bay, East-Indian Company type could never been created on land. The algorithm of their development directly depends on maritime traffic, a relatively cheap, but irregular means of water transport, "going overseas". During the entire economic history of Siberia, there have never been any economic or political superorganizations that would control the whole of its territory, and its size is not the only reason. The main obstacle was the overland transportation; it broke the classical algorithm of development and existence of super-organizations depending on sea transport and navigation. For this reason, the classical colonial conquering pattern was not efficient in Siberia. Extraction of Siberian resources has been challenging in all historical periods, requiring large investments into the transport infrastructure. That drew strong and regular strengthening of connection to the "continental" Russia, which is absolutely impossible in the "maritime" exploration pattern (relatively cheap in comparison to the overland one, but irregular and discreet in the communications between the colony and its mother country).

In the imaginary scenario where Siberia is surrounded by sea and becomes a super-island, it is a real colony, where the Russian state establishes an economic and political super-organization for the exploration of its natural resources. Just like Canada, Australia, New Zealand, Greenland, or Brazil, this island colony would one day get a status of an independent state and sovereignty.

But the ultimate binary "yes-no" logic has never worked for Siberia; historically, it has always attracted more compromised, "blurred" 
political and economic models. Due to its ultracontinental nature, the case of Siberia is extremely special. Being a country's periphery, not a colony, Siberia preserved its status of an overland remote territory, with a tight, but faulty connection with the Central Russia, for ages. The underlying physical and informational periphery was the factor that has always determined the specificity of economic development of Siberia: for example, on one hand, it implied re-invention of the items known in more developed districts; and on the other, great attractiveness for marginal strata and religious confessions, such as Old Believers.

It is very important to draw a border between colonial and peripheral character with the doubtless thesis of the ultracontinental character of Siberia, since its colonial and peripheral nature needs to be treated differently. It is not an issue of methodological studies; it is a question of practical national policy.

Coloniality requires political independence from the mother country. The periphery, on the opposite, needs to strengthen its transportation, information, financial, energetic and personal connection to the centre. This is how Siberia was to develop according to the Soviet super-project, when all the republics of the Union participated in it together with Central Russia. For the successful economic development of Siberia, being connected to all developed territories of Russia in a variety of ways is important like for no other region. This is when the actualization of the Siberian transit potential is the direct way to overcome its peripheral character. This is why for Siberia large transportation mega-projects bear more than just transportation, but also a political and economic meaning in terms of neutralization of the negative effect of its peripheral character, its specific overland enclave-like situation ${ }^{5}$.

Myth 2. Russian resource extracting companies are being irresponsible and selfish in
Siberia. Corporativity is an essential peculiarity of Siberian economy, commonly found in many regions of Siberia. The unique and rich deposits of West and East Siberia are really attractive for the leading Russian resource-extracting corporations. They make an enormous influence on the economic and social development parameters of Siberian territories.

They are often accused of opportunistic "cream skimming" without returning a share of the earnings to the territory where the resource was found. In comparison to large state trusts and management boards who explored Siberian resources in the Soviet times, today's corporations are obviously much more selfish.

Despite all the criticism, the state enterprises functioning in Siberia during the Soviet era bore more social responsibility than the contemporary corporations. But it should be noted that in those times the subject matter was a deposit of fresh and unique resources, being the only option for the economically isolated country and so acutely needed (at that moment, they seemed inexhaustible and almost free to extract). Due to their volume, they ensured "Siberian" economic efficiency which could compensate for anything, including Siberian margin, the distance factor, the lack of energetic infrastructure and low population density. That effect and the natural assets were the basis for forming acceptable living standards for the Siberian pioneers of the 1970-1980-s.

Exploration of Siberia was based on the saving effect of the crazy volumes, enormous deposits of unique minerals and extremely high content and concentration of natural assets. However, with the ageing of the main resourceextracting provinces and deterioration of the main production capacities combined with new Russian economy's liberal openness to the world allowing purchasing resources with less expenses, the effect lost its power. 
Now the subject matter is the exhausted resources or new deposits with medium concentration and/or challenging extraction conditions, which have lost the attractiveness for Russian companies they had 50 years ago (both due to their youth and the absence of options in the isolation of the world markets) in comparison to their foreign analogues. The time of cheap Siberian resources that provided problem-free existence for both Siberia and the country as a whole has gone. For this reason, it is not fair to reproach the resource-extracting companies that still continue exploration of Siberia.

So, is there or is there no any Siberian rent from natural resources exported to the West by the companies, without satisfying the current need for innovative modernization of the production facilities and violating their social obligations to the territory of extraction? There is, but it is selective, enclave-like, applicable to certain types of natural resources, where Siberian distancerelated expenses can be avoided, or when the Chinese customers are close, or due to the easy transportability of the ultimate super-valuable product (gold, palladium etc.).

The main reproach on the current position of Siberia should be addressed not to the "selfish" resource-extracting companies that behave logically and appropriately in the global competition, but to the state, that has handed its moderating function over to the corporations and transformed into a collective lobbyist that adjusts its tariff, licensing, and price policy to the needs of the companies in this nature-use sphere that is vital for Siberia. In respect to Siberian regions, small businesses and other economically weak actors, it runs a unified policy that makes no difference between economically dense regions of Central Russia, where market powers emerge by themselves, and scarcely populated Siberian territories, where market economy cannot be developed by definition, and where naturally appearing local monopolies need active and powerful regulation with governmental price and tariff policies.

Let us repeat, that instead of establishing common playing rules for large Siberian resource-extracting corporations and making fine adjustment of measures for supporting weaker economic players represented by Siberian regions, municipalities, and entrepreneurs, the state prefers a fine "lobbyist" adjustment for stronger economic players, or large companies, and, on the opposite, an ultimately unified policy for weaker ones.

There is no problem of irresponsibility of the resource-extracting companies working in Siberia; there is a problem of weakness and inefficiency of the governmental regulation of the Siberian economic processes, including basic nature use. Siberia and Siberian economy can be referred to as a hostage of incompetent and inefficient governmental policy in the sphere of nature use and resource management. Since Siberian economy is, this far, based on extraction and processing of natural resources, it pays the price of the imperfection and inefficiency of the modern governmental nature-use regulation.

The state's lobbyist approach to the interests of large companies manifests itself in the last 25 years' hostility to any attempts to create a legal stratum of small and medium-sized businesses in the sphere of nature use, including those operating the resources exhausted during the last half a century. These assets are of no more interest for large companies, but they cannot be trusted to small businesses either, for they are subject to multiple prohibitions and bureaucracy. It leads to the classic contradiction between production capacities and production relations described by K. Marx: natural assets are exhausted, while the main institutions, regulations and rules still remain unchanged since the "oil fountains" times, letting no one but large subjects operate the 
resources. This "micro-Marxism in action"6 costs dear for the Siberian economy when many natural sites are perfect for small and medium-sized enterprises due to their exhaustion, heterogeneity or medium concentration of deposits.

As we found, the key to Siberian economic problems is not irresponsibility of the resourceextracting companies, but wrongly determined priorities and weak state regulation of subsurface resources management, that, due to its resource nature, costs for Siberia more than for any other federal district. But there is another gap in the governmental efforts in Siberia, that becomes obvious at the comparison of return on assets and sold goods in the extracting and processing sphere versus those in the sphere of electric industry (Table 4).

The data shown in Table 4 reveals that the most profitable enterprises in Siberia are not the extracting, but the processing ones, that are less sensitive to the factors of ultracontinental character and remoteness of the Siberian economy. Moreover, Siberian processing of natural resources (majorly non-ferrous, but also ferrous metallurgy etc.) is the most profitable in Russia. It also has the most profitable electric industry.

Siberian distances to the closest consumption markets take a heavy toll of the initial high profitability of the resources. On the other hand, distances do not affect the final profitability of processing and electric industries that much. But it means the necessity for the global state encouragement of developing processing stages at long-term extraction sites operated by resource-extracting companies, small and medium-sized businesses. Our colleagues refer to this strategy as "creating ecologically closed regional technological systems with high degree of processing local raw resources to produce a wide range of science-intensive products" changing properties of natural resources also stimulate territorial localization of extraction and processing: large-scale homogenous deposits leading to volume-based savings are involved in operation less and less, and more often the heterogeneous compound deposits with a "mixed composition" of elements, large deposits with medium or poor content of the resource are preferred. The hybrid character of the new Siberian deposits dictates brand-new forms of production capacities arrangement, for instance, combination of extraction and processing at one site, that the state needs to encourage the new subsurface users of Siberia to do.

Myth 3. Due to its distinctive latitudinal division, Siberia has good prerequisites for developing connections between the "northern" and "southern" enterprises. The last decades' reality proves the opposite. The division of Siberia into the canonical latitudinal zones does not facilitate, but prevents the inter-firm cooperation, for the natural and climatic conditions of the zones are dramatically different, making it impossible to apply, for instance, brand-new agricultural practices of one latitudinal zone in another (which is typical, for example, for the "multizonal" Altai Krai). It also applies to construction: techniques matching the conditions of the Siberian south are sometimes inacceptable in the Siberian Arctic. Therefore, Siberian zonality creates barriers for the intra-Siberian economic integration. The fact that after 50 years of active economic activity Siberia still has not developed an integrated market or intra-Siberian system of labour division, can be interpreted as a result of fundamental differences in the natural conditions of each latitudinal zone (steppe, taiga, and tundra).

It is true, that in the Soviet time, despite the calls for "friendship between the south and the north", this economic cooperation has never been achieved; exploring its resources, Siberia mostly cooperated with the country as a whole, 


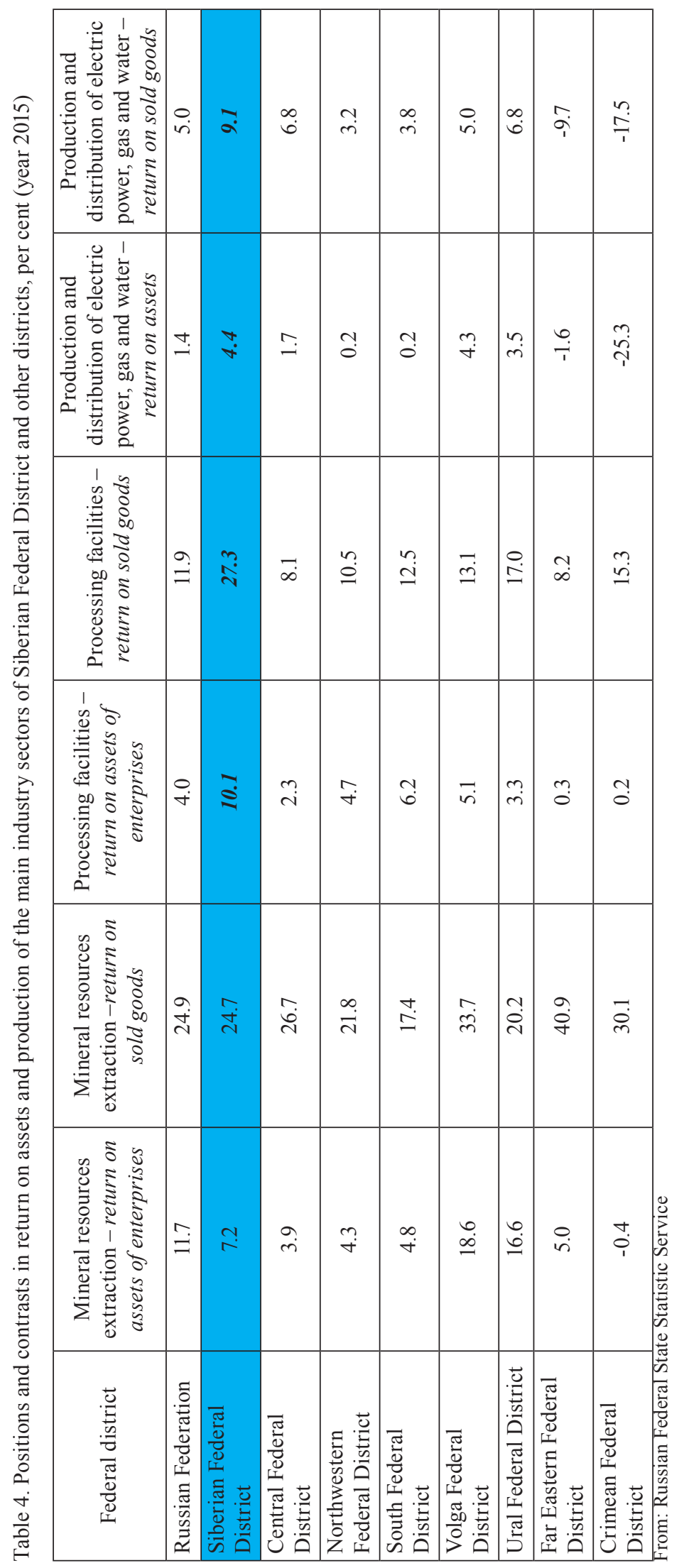


instead of developing intra-regional interaction within its constituent parts. The situation was aggravated with the radical economic reform of 1992, when the export-orientation of the main resource-extracting facilities of Siberia revealed a dramatic internal dissociation of Siberian economic system, oriented more to Russia and the world than to other Siberian territories.

This is the reason why the policy on encouraging internal cooperation between Siberian southern extracting and servicing, and northern extracting enterprises for economic partnership, economic concentration and strengthening Siberian inter-firm cooperation is promoted as a priority task of modern Siberian governmental policy. Both old and newly established development institutions should be oriented to this purpose.

Even simple comparison of the volume and composition of the latest industrial production catalogues of all federal districts for the needs of the Arctic zone proves that there is still a lot to be done in the sphere of economic integration between the north and the south. For example, in the volume of supply Siberia still drags behind not only Central, but also Ural and Volga Federal Districts (Table 5).

The fact of the latitudinal zonality of Siberia automatically means no cooperation between "northern" and "southern" enterprises, such as extracting firms of the tundra area and processing facilities of the steppe and taiga zones. It is just a prerequisite, an opportunity that will never be actualized in the liberal market economy due the freedom in partner selection. Only active encouragement and stimulation of the intraSiberian cooperation by the state may lead to the desired alliance. It is an issue of an active and focused governmental policy.

\section{Prerequisites and conditions \\ for creating a new model for exploration of Siberia (what can we rely on?)}

All attempts to develop a new development model for Siberian economy and a new model of exploration of Siberia, that would not follow the trends of the last decades of the Soviet period but come up with a brand-new ideology, need to rely on the existing economic history of Siberia on one hand, and hear the tendencies of the last two decades on the other. For this reason, the first two paragraphs of the chapter are dedicated to the Path-dependency, i.e. the genetics of Siberian development that has been established in the past centuries; and the last two paragraphs are dedicated to the new tendencies that have recently revealed themselves or have just got studied.

Table 5. Basic catalogue of high-technology industrial products and services for the needs of the Arctic territory of the Russian Federation (Ministry of Industry and Trade of Russia, 2016)

\begin{tabular}{|l|c|}
\hline & Number of pages \\
\hline Ural Federal District & 110 \\
\hline Central Federal District & 100 \\
\hline Volga Federal District & 65 \\
\hline Siberian Federal District & $\mathbf{5 5}$ \\
\hline Northwestern Federal District & 48 \\
\hline Far Eastern Federal District & 26 \\
\hline South Federal District & 25 \\
\hline Northern Caucasus Federal District & 19 \\
\hline
\end{tabular}




\subsection{Industry - state, agricultural \\ development - entrepreneurship}

Since the 19th century, economic theory of Siberia has proved that the main subject of its industrial development is the state, while agricultural one is driven by entrepreneurship. For this reason, the idea of handing Siberian industry over to the market, expressed in the early 1990 -s, was not just wrong, but also contradicted local traditions, developed as a result of a long evolution of property institutions, industrial enterprises and transport infrastructure. The local industry has never had enough large economic subjects for the market self-development powers to emerge, which made the state the main subject of exploitation.

On the other hand, in the agrarian sector of Siberia, especially its grain area, private incentive and farms have historically been well-developed. Traditionally, Siberian entrepreneurs have hardly interfered in industrial activity, and in the majority of districts they still prefer to concentrate on food and wood processing ${ }^{8}$.

Modern entrepreneurship of Siberia is a controversial matter. On one hand, the territory holds the third place among federal districts on the number of small business per one thousand people of population and the first on the share of farmers in grain production; however, in the share of residential houses built at the expense of population (an indicator that indirectly reveals entrepreneurship activity of the citizens) Siberia occupies one of the last positions among other federal districts (Table 6).

The picture of entrepreneurship potential distribution among Siberian regions also looks controversial (Table 7): the leader is more than 6 times ahead of the outsider. The absolute leader in entrepreneurship activity in Siberia is the Novosibirsk Oblast. Basically, it has no large corporate structures, and small businesses (mostly in the areas of trade, construction and transport) forms the fact of the whole regional economy. It is far behind followed by the Krasnoyarsk Territory (Krai) and the Tomsk, Omsk Oblasts. The Trans-Baikal Krai and the Republic of Tuva are at the bottom of the list with absolutely tiny official entrepreneurship activity indicators (most of them, especially those in the areas of mining, forest industry, and cattle breeding, remain in the shade).

Obviously, production entrepreneurship with no historical roots in Siberia, is expected to be specific and original, both as a sort of partnership with large resource-extracting businesses and independently on its own. It is also evident that without entrepreneurship energy in the extracting and processing industries as well as energy sector, the new model of development of Siberia can never emerge.

Table 6. SFD rating among other federal districts in the year 2015

\begin{tabular}{|l|c|}
\hline \multicolumn{1}{|c|}{ Indicator } & \multicolumn{1}{|c|}{ SFD rating } \\
\hline Number of small businesses per 1000 people & 3 \\
\hline $\begin{array}{l}\text { Family farms' share in the structure of main agricultural goods' } \\
\text { production - grain }\end{array}$ & $\begin{array}{l}1(34.6 \%) \text { (leaders: Republic of } \\
\text { Khakassia, Altai Krai, Irkutsk, } \\
\text { Kemerovo, Omsk Oblasts) }\end{array}$ \\
\hline $\begin{array}{l}\text { Specific gravity of residential houses built by the population for } \\
\text { their own or borrowed funds, in the total amount of commissioned } \\
\text { residential houses (per cent) }\end{array}$ & 8 \\
\hline
\end{tabular}


Table 7. The existing entrepreneurship potential is unevenly distributed (year 2014)

\begin{tabular}{|l|l|}
\hline & Number of small businesses per 10000 people \\
\hline Russian Federation & 144 \\
\hline Siberian Federal District & 156 \\
\hline Novosibirsk Oblast & 278 \\
\hline Krasnoyarsk Krai & 187 \\
\hline Tomsk Oblast & 178 \\
\hline Omsk Oblast & 155 \\
\hline Altai Krai & 134 \\
\hline Republic of Khakassia & 126 \\
\hline Kemerovo Oblast & 124 \\
\hline Irkutsk Oblast & 118 \\
\hline Republic of Buryatia & 114 \\
\hline Republic of Altai & 106 \\
\hline Trans-Baikal Krai & 59 \\
\hline Republic of Tuva & 42 \\
\hline
\end{tabular}

From: Russian Federal State Statistic Service

\subsection{Siberia exploration speed: the role of pauses in exploration}

Spatial arrangement of Siberian economy is not the only one that has clearly diagnosable peculiarities (ultracontinental character, remoteness from the main national centres, zonality, corporativity). Its temporal arrangement, its chronic structure is also distinctive. The specificity is the opposition to the linear ascendance associated with progress in the West.

Continuous advance has never been typical of exploration of Siberia. Thus, for example, an outstanding expert in Siberian development, an economist geographer from Irkutsk V.V. Pokshishevskiy wrote: "From time to time, Russian colonization seemed to "choke" on the disproportion between the area of the discovered territories and the number of people occupied in industry and administration" ". Almost 65 years later, another Irkutsk economist geographer V.I. Blanutsa in his Doctor's thesis arrived at a similar conclusion based on rich historical material: "Every time after establishment of another post office on the way to the Pacific ocean, there was a peculiar step back for opening a post office in the opposite direction. It was usually followed with another leap eastwards"10.

This "choke" or making one step back in time has always been peculiar of economic exploration of the Siberian territories. I would take the risk to generalize, that it was specific not only in the establishment of post, but for any novelties spread around Siberia, such as new extracting facilities, transportation routes, new means for "merging" Siberian territories etc. At first, there would be a breakthrough to something new, such as reaching the Pacific ocean or covering a large distance in one go due to a large governmental transportation route construction project, followed by a pause, which was needed for digestion and arrangement of the novelty in Siberia, before making another step forward.

This "interval" pattern perfectly fits the selective manner of exploration of Siberia (described by S.V. Slavin in the 1930-s, speaking of the North): focal selectiveness of economic 
exploration of the unique natural resources is combined with the through-going linear manner of building transportation routes and the entire territorial structure of exploration. The "throughgoing character" of the linear tracks and hubs of exploration takes time to solidify.

Here comes a natural question: is the current step back/compression of the explored Siberian space followed by internal concentration in urban agglomerations and metropolitan areas the forced step back required to "digest" everything that was grasped so fast and cursorily during the Soviet era?

\subsection{Siberian type of communication}

Siberian regional science pays special attention to the communication between subjects of economy: the forms, speed, organizational and technical mechanisms and institutions that keep it going. It is common to believe that the success of an innovative process directly depends on the regular, direct, personal, easy and fast Internet communication. It is explained by the fact, that face-to-face and computer communication do not compete with each other, harmoniously complementing each other and increasing each other's efficiency.

That is why it is impossible to ignore the local communication phenomenon when developing a new model for economic development of Siberia. What is it like in comparison to other federal districts? Is there any Siberian specificity? To what extent is the current communication between the economic subjects acting as a barrier, or can it, on the opposite, facilitate new development of Siberia?

It is clear that communication directly depends on the level of real income of the population, on the people's capacity to pay for communication. However, this phenomenon is too important for modern economic development to be restricted to a simple derivate of the average income. It is an independent indicator, which, importantly, can be influenced separately and directly, avoiding the "drive belt" of increasing per capita income.

The type of communication dominating in Siberia is tightly connected to its exploration model, which gives us a key to the phenomenon of Siberian economic development as a whole, not communication alone. For example, it is known that Siberia was explored through the meridian river systems and latitudinal roads (later, highways) that shaped up the territorial pattern of the exploration process. As the latitudinal motorways and railway tracks grew stronger, the "latitudinal" type of communication was established as regular personal communication between people living along the routes of exploration by means of post and telephone connections.

Later, when the development of Siberia arrived at a pause, the "natural" channels of communication along the Siberian rivers were activated; in the 1930-1960-s, the meridian, "river" communication between the south and the north dominated both in personal communication and in post and telephone connection. That was when the physical and geographical division of Siberia into West and East was established in economic and geographic literature.

Later in the period of active economic development along the overland latitudinal tracks and the Northern Sea Route, as well as a result of active pioneering air communication and powerful agricultural development of the Siberian south (agriculture is always exceptionally zonefocused, which raises the priority of the zonal factor and zonal differentiation of the territory), the latitudinal division of Siberia into the Far North (Arctic), Near North and the South became dominating. There is no surprise that it was the time when the article, and later, the monograph edited by academician A.G. Granberg "Siberian 
economy in the latitudinal zones aspect" was written ${ }^{11}$.

A change in the concept of stratifying Siberia was well formulated by academician N.N. Nekrasov in his book: "Today, the meridianwise division of Siberia (West and East) loses its scientific and practical meaning. The previous pattern of division is now replaced with the latitudinal one, which better reflects the specificity of natural and climatic conditions of separate

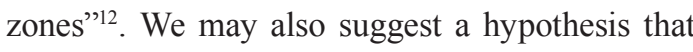
in the periods of active exploration of Siberia, latitudinal communication along the latitudinal transportation routes and tracks dominated, while during the periods of pauses (compression of exploration) the "natural" (physical and geographic) communication along the streams (basins) of the great Siberian rivers took over.
The most important conclusion to be made as a result of comparing Siberian performance with that of other federal districts is the following: here the "slow", traditional forms of post communications dominate, and in this term Siberia is on the top of Russian rating. As for the "rapid" forms of communication, such as cellular communications, courier post, even regular local fixed telephone service, Siberia is at the bottom (Table 8). Combined with the wellknown fact of minor mobility of the population, it means absolute peripheral character of communication (which can be regarded as one of the consequences of the ultracontinental, "pushed back" character of Siberia in respect with the main markets), slow exchange of ideas, and, consequently, significant intellectual conservativeness.

Table 8. Siberia: more slow, less rapid means of communication

\begin{tabular}{|c|c|c|c|c|c|}
\hline & $\begin{array}{l}\text { Number of cellular } \\
\text { communication } \\
\text { subscriber devices } \\
\text { per } 1000 \text { people, } \\
2015\end{array}$ & $\begin{array}{l}\text { Specific gravity of } \\
\text { postal service in } \\
\text { the total volume } \\
\text { of communication } \\
\text { service, } 2009\end{array}$ & $\begin{array}{l}\text { Specific gravity } \\
\text { of EMS service in } \\
\text { the total volume of } \\
\text { postal services, } \% \text {, } \\
2009\end{array}$ & $\begin{array}{l}\text { Specific gravity of } \\
\text { rural settlements } \\
\text { not covered by } \\
\text { postal services } \\
\text { network, } \%, 2009\end{array}$ & $\begin{array}{l}\text { Number of } \\
\text { stationary phones } \\
\text { connected to the } \\
\text { public network per } \\
1000 \text { people of the } \\
\text { urban population, } \\
2015\end{array}$ \\
\hline Russian Federation & 1937.8 & 7.0 & 2.4 & 5.0 & 197.3 \\
\hline $\begin{array}{l}\text { Northwestern } \\
\text { Federal District }\end{array}$ & 2340.4 & 6.4 & 1.9 & 3.3 & 236.4 \\
\hline $\begin{array}{l}\text { Central Federal } \\
\text { District }\end{array}$ & 2219.7 & 7.1 & 4.7 & 8.5 & 247.3 \\
\hline $\begin{array}{l}\text { South Federal } \\
\text { District }\end{array}$ & 2037.7 & 6.9 & 0.3 & 1.6 & 164.2 \\
\hline $\begin{array}{l}\text { Ural Federal } \\
\text { District }\end{array}$ & 1986.3 & 5.4 & 0.7 & 4.8 & 161.2 \\
\hline $\begin{array}{l}\text { Volga Federal } \\
\text { District }\end{array}$ & 1808.4 & 7.7 & 0.3 & 2.1 & 189.6 \\
\hline $\begin{array}{l}\text { Far Eastern Federal } \\
\text { District }\end{array}$ & 1805.9 & 7.9 & 1.2 & 1.5 & 182.2 \\
\hline $\begin{array}{l}\text { Siberian Federal } \\
\text { District }\end{array}$ & 1742.0 & 7.8 & 0.4 & 1.7 & 158.1 \\
\hline $\begin{array}{l}\text { North Caucasian } \\
\text { Federal District }\end{array}$ & 1338,7 & & & & 102,7 \\
\hline $\begin{array}{l}\text { Crimean Federal } \\
\text { District }\end{array}$ & 70,6 & & & & 71,4 \\
\hline
\end{tabular}

From: Sviaz'v Rossii. 2010 [Communications in Russia. 2010] reference book. Moscow: Rosstat 
Of course, it is a negative basis for forming new concept of Siberian development. To our mind, it requires some focused efforts to ensure its greater involvement into national and international information exchanges than today, made in any possible ways: through foreign investors, information transfer centres, international forums, seminars, exhibitions, internships etc. For Siberia, any measures on providing exchange of ideas and information are much more significant than for any other Russian federal districts, for the reason its "pushed back" economic and geographic position. Economic history of Siberia also proves that every breakthrough in its development happened after a fruitful transfer of ideas, technologies, and competences carried out by foreign or Russian specialists. For example, the contemporary history of Kuzbass Basin began with a German colony of experts in coal and metal industry, who shared their Ruhr exploration experience in the 1930-s.

Another important conclusion on Siberian communication is the following: the performance of Siberian village is much better that in entire Russia in general and in many other federal districts, and it is much better than the position of Siberia in term of urban telephone network coverage (Table 9). Here is what is so unique about Siberia: in terms of rural telephone network coverage and farming activities, the village turns out to be much better prepared for innovations and acceptance of a new economic development pattern than an average Russian village or villages of other federal districts. Therefore, it is an important, but yet underestimated reserve for the economic breakthrough of this macro-region.

Inside Siberian Federal District, the bottom of the rating on rural and urban telephone network coverage is occupied by territories belonging to Baikal macro-region (the Irkutsk Oblast, the Republic of Buryatia and the Trans-Baikal Krai), as well as the Republics of Altai and Tuva. First of all, they represent the so-called "Diaspora" Siberia, i.e. place of compact residence of the Old Believers as well as "other ethnicities that arrived in Siberia as a result of repeated transfer due to religious, political, and economic circumstances $^{13}$; secondly, they are the cores of the surviving cultural and ethnic traditions (Republic of Tuva, and partially the Republic of Altai); thirdly, they are true "backwater districts", the most peripheral and hard to access territories of Siberia. Here the new information impulses cannot penetrate without a certain spatial friction, which requires special effort for telecommunication arrangement. For example, it is a known fact that the border areas of the TransBaikal Krai pick up signals of Chinese mobile operators much better than those of Russian ones.

\subsection{Siberian cities and Siberian creativity}

There is a great number of strategic tasks of Siberian development that is not city-oriented, but focused on large urban agglomerations, such as establishment of a facility of intellectual business services, industrial service (financial, insurance, legal, consulting, project, office, communication, touristic infrastructures for businesses). Due to the low density of Siberian spaces and great transportation transaction expenses, large cities play an extremely important role in the modern development of the macro-region, which is comparable to or even overcoming that of the large resource-extracting facility building projects of the late Soviet period. To put it better, in the past decades, large Siberian cities have become a new factor of economic growth and development of the micro-region, comparable to the large resource-extracting facility building projects of all-national scale. The relative role of large Siberian cities in the development of Siberia is doubtlessly greater than that of the urban agglomerations in other federal districts, due to 
Table 9. Siberia: rating on rural telephone network coverage much better than that on the urban one

\begin{tabular}{|c|c|c|c|c|}
\hline & 2005 & 2010 & 2015 & $\begin{array}{l}\text { Rating in the Russian } \\
\text { Federation, } 2015\end{array}$ \\
\hline \multicolumn{5}{|c|}{$\begin{array}{l}\text { Presence of telephones connected to public network per } 1000 \text { people of urban population (as of end of the } \\
\text { year; items) }\end{array}$} \\
\hline Russian Federation & 268.1 & 273.2 & 197.3 & \\
\hline Siberian Federal District & 238.3 & 249.6 & 158.1 & 7 (of 9) \\
\hline Novosibirsk Oblast & 265.7 & 288.4 & 194.9 & 34 \\
\hline Altai Krai & 258.8 & 281.4 & 191.1 & 37 \\
\hline Tomsk Oblast & 307.0 & 293.8 & 178.4 & 46 \\
\hline Omsk Oblast & 223.0 & 247.1 & 178.0 & 47 \\
\hline Krasnoyarsk Krai & 252.5 & 260.5 & 148.0 & 63 \\
\hline Kemerovo Oblast & 220.5 & 227.0 & 140.3 & 69 \\
\hline Irkutsk Oblast & 237.6 & 240.1 & 139.9 & 70 \\
\hline Republic of Altai & 224.6 & 216.1 & 132.6 & 73 \\
\hline Republic of Khakassia & 211.4 & 224.4 & 130.2 & 74 \\
\hline Trans-Baikal Krai & 165.8 & 194.3 & 129.7 & 75 \\
\hline Republic of Buryatia & 204.2 & 192.9 & 119.0 & 77 \\
\hline Republic of Tuva & 148.3 & 131.1 & 68.4 & 81 \\
\hline \multicolumn{5}{|c|}{$\begin{array}{l}\text { Presence of telephones connected to public network per } 1000 \text { people of rural population (as of end of the year; } \\
\text { items) }\end{array}$} \\
\hline Russian Federation & 113.2 & 117.8 & 93.1 & \\
\hline Siberian Federal District & 112.7 & 128.1 & 101.6 & $4($ of 9) \\
\hline Tomsk Oblast & 207.7 & 227.3 & 188.2 & 2 \\
\hline Altai Krai & 157.0 & 175.4 & 160.9 & 6 \\
\hline Novosibirsk Oblast & 134.6 & 167.4 & 147.3 & 10 \\
\hline Omsk Oblast & 108.8 & 126.8 & 98.6 & 35 \\
\hline Republic of Khakassia & 112.2 & 121.4 & 91.7 & 40 \\
\hline Krasnoyarsk Krai & 98.2 & 114.6 & 80.9 & 50 \\
\hline Republic of Buryatia & 94.6 & 108.5 & 70.1 & 61 \\
\hline Republic of Altai & 111.0 & 127.0 & 68.8 & 63 \\
\hline Trans-Baikal Krai & 61.6 & 86.1 & 66.0 & 64 \\
\hline Kemerovo Oblast & 80.8 & 78.7 & 54.2 & 70 \\
\hline Irkutsk Oblast & 52.2 & 50.2 & 31.1 & 78 \\
\hline Republic of Tuva & 42.7 & 38.8 & 9.5 & 80 \\
\hline
\end{tabular}

the low density and development level of Siberian spaces.

Siberian urbanization is a specific phenomenon. Unlike the central districts, it explores its territories selectively, erratically, not entirely, through a network of outposts and local exploration bases that control local, regional or larger territories.
Large Siberian cities shape up a creativity model, different from the European one, based on the regional (multizonal, terrain) diversity. European creativity model is based on the urban diversity (after Jacobs), that comes from the colossal cultural, ethnical, axiological pluralism of modern European and American cities. But Siberian cities are too young to have such a model 
established. Their creativity is nourished by large-scale migrations of young talented people from all around the large Siberian region, oblast, or republic, who gather in a large regional centre like Krasnoyarsk, Novosibirsk, Omsk, Irkutsk, Bratsk, or Tomsk.

Just like compact creative regions of Central Russia accumulate talents from all over the country, Siberian centres concentrate opportunistic creative youth from all over the colossal regional territory. They are the regional "melting pots", centres of mixing ethnicities, cultures, lifestyles, bringing bearers of different knowledge together. The creativity of the regions is nourished by the intensive periphery-centre oriented intraregional migration of the energetic people. The high creativity index of the region is ensured with the successful creative and innovative activity of the republican, krai and oblast centres.

The greater is the variety of terrains within one regional contour (the terrain diversity effect normally depends on the size of the region), which is a natural pre-requisite for ethnical and cultural diversity, the better are the conditions for pluralistic creative cities with rich spiritual life. For this reason, Siberian regions (not being a common destination of Russian and foreign migrant) with their huge territories, other conditions being equal, have better chance to be creative that the compact ones, due to their potential of forming unique diverse, multicultural local community of talented migrants from all of its corners. For example, the Krasnoyarsk Territory (Krai) is a region of wide spaces, stretching through several geographic zones, uniting both colossal scarcely populated territories and middle-sized cities. Just like compact creative regions of Central Russia accumulate creative people from all over the country, the centres of large territories concentrate opportunistic talents from the whole enormous territory of the region ${ }^{14}$.
The specific Siberian model of creativity confirms that Siberia should not hope for the success of the Silicon Valley model based on great density of population and intensive communication between its residents. Here the innovation process develops on a different model, that can constructively make use of the isolated and peripheral nature of the wide Siberian territories.

\section{New paradigm of Siberian development}

The classic paradigm of exploration of Siberia is clearly set forth in the book by N.N. Nekrasov "Problems of the Siberian complex" that can be referred to as an ode to the scale effect. The author writes that the "main tendency of the modern period is the search for large deposits, basins, provinces, and districts of mineral concentration"15. That was what Siberian economy used for the exploration of unique, super-large deposits of oil and gas of the Western Siberia. The scale effect of super-efficient Siberian deposits compensated the expense-increasing factors of severe climate and ultracontinental nature. Thanks to this effect, the expenses borne by the national economy during the first exploration period in the 1970-s were lower, not higher, than in the explored districts of the country.

Here rises the following question: what new economic effects do we want to rely on during further economic development of Siberia? Or, recalling the classical works of the Nobel Prize winner Paul Krugman, where are the effects of increasing returns on Siberian spaces found?

Of course, the most daring solution comes from the aspect of opportunities, not that of barriers or initial disadvantages. We should not excuse Siberian isolation or ultracontinental nature, but admit the global uniqueness of Siberia and see the ways to take advantage of its autonomy (information periphery and physical 
isolation of Siberia from the main large markets), and, therefore, its originality. This is the most basic postulate for further solutions for the development of Siberia.

We can therefore state the following. For Siberia, the endogenous economic growth ideas dominating in today's economic mainstream mean relying on its ultracontinental nature, corporativity and zonality as on the fundamental properties of its economy and efficient use of these properties in the interests of the macroregion.

In Siberian territories, the increasing returns idea means getting effect from the large and dispersed urban agglomerations, fundamental economic districts forming the localized platforms of local economic clusters; contact territories of the Siberian Russian-Chinese border territories. Unlike the previous, late Soviet time, all these effects involve the efforts of small and mediumsized businesses that generate them through the active interaction with large resource-extracting companies of Siberia and with each other.

As it was remarked in the Strategy of Development of Siberian Federal District ${ }^{16}$, over 90 per cent of today's gross regional product of Siberia is produced on the area occupying less than 10 per cent of the Siberian territories. It has never been like that! We witness crazy concentration of the previously scarce economic space with simultaneous compression (contraction).

Of course, it would be impossible to achieve the increasing returns in the territories of the Ural-Kuznetsk industrial combine scale, or the "greater N.N. Kolosovsky district"17. These effects can be generated only within small, local contours, ensuring intensive, dense, and regular personal communication between the subjects of economy we refer to as "small economic districts of Alaev-Becattini”. Exterior economy and externalities have never mattered as much in greater districts of Kolosovsky as they do now! The new effects of "infecting" them with novelties do work in this basic lesser economic districts of Alaev-Becattini.

New exploration of Siberia has always relied on the new resources of its territories. A new stage of development has never been based on the avant-garde resources of the previous stage of exploration. Who can be a candidate to be a new leader? First of all, water (sweet water and irrigation resources) and agrarian resources of the $21^{\text {st }}$ century Siberia, which can give birth to a new macro-specialization of Siberia, interesting for its nearest Middle Asian neighbours and China. One of pre-requisites of this new specialization was the outstanding Soviet mega-project on turning the Siberian river streams to the cotton plantations of the Middle Asia. Today, Siberian agricultural and water resources have a chance to become the most important Siberian export product. There are some preconditions that prove it. For example, a new unique branch of specialization is intensive growing of strawberries in Slyudyansky Districts of Irkutsk Oblast ${ }^{18}$.

The agriculture with its bustling energy and comparatively good communication equipment can be assigned some larger-scale tasks than just supplies of food and security. The agricultural resources of Siberia should serve the internal Asian markets of Mongolia, China and Middle Asian countries. This is how the disadvantages of the ultracontinental character and periphery, wide unexplored spaces of Siberia seen as such in terms of cooperation with the European and American markets, turn inside out and look like a valuable potential for partnership with the rapidly developing markets of the nearby Asian states.

A bright example of unexpected turning Siberian disadvantages in one aspect into advantages in another, of this specific dialectics, is the phenomenon of economic and geographic position (EGP), perceived not in the traditional, single-level way, but as a polyphony of global, 
national, regional and local EGP. And for real, the EGP of Siberia, closed from the point of view of access to global and main national markets, happens to be exclusively profitable if regarded on the local and regional levels, as proximity to some provinces of the rapidly developing China.

As we can see from the example of the Trans-Baikal Krai, the border transformation into a contact area can serve as a powerful economic impulse for development, making the agricultural resources of the vast Siberian spaces work for the growing consumer market of China. The Trans-Baikal Krai could become a perfect case-study, being a region where the borders have been always seen as a barrier (and the territory itself - as a military and civil outpost of Russia in Asia), transforming into a pilot region for the borderline cooperation, actively encouraged and controlled by the federal government, where the barrier-borders are turned into the contact zone. The profits of proximity to China are capable of compensating for all the disadvantages of the global and national EGP of Siberia for the local economy (for example, through creating the socalled "dry ports", or large customs and logistic zones along the Chinese border).

For many decades of Siberian industrial exploration, Siberian "desertedness" has-been seen as doubtless evil that needs to be overcome with all possible efforts of the state. Here the deception of N.N. Nekrasov, who formulated this opinion, looks especially insightful: "Territories with the most challenging natural conditions become accessible for economic activity. The times of "reserve" territories with no definite economic purpose that were practically left out as deserts, are over $^{19}$. Therefore, the reserve territories of Siberia represent the evil that needs to be overcome by making them accessible and getting them involved into the national economic turnover.

But now, against the background of the global requirements for environmental care and resource saving, we see and appreciate the desertedness and economic inaccessibility of Siberia as an opportunity to preserve some pieces of the virgin lands for the world and the country as a reserve of large deposits for future exploration. Or, even better, as a new large specialization of Siberia within Russia: to reserve some parts of land and subsurface for the sake of the future (future generations and future development).

From the point of view of reservation, the conceptual peculiarities of Siberian nature have been clearly formulated by E.E. Syroechkovsky: the ultracontinental climate, diverse terrain, Baikal lake, Siberian rivers flowing into the Arctic ocean, permafrost, rocks and structures of various geologic ages, variety of landscapes and taiga as the greatest extra-tropical forests of the world. ${ }^{20}$

The economic feasibility of reserving and preserving Siberian spaces is especially obvious in the periods of falter, of pauses in the former economic exploration. As we can see, the reserve territories institution could be very useful for Siberia. This idea has the core of outfitting the new unexplored spaces of Siberia, intentionally left out as such for another long term and assigned with this official status.

It is life itself that forces us to admit the official reserve territory status: we see, how many Siberian deposits have been unfairly abandoned after long and enthusiastic efforts on unavoidable exploration in the 1990-s (e.g., Udokan, Sukhoy Log, Tomtor etc.) due to the economic inaccessibility and low feasibility of exploration. They need the official reserve status for the future generations. And, on the opposite, a known reserve coal deposit in Taimyr has recently become a point of growth and attraction for many investors. The new Taybass caused a wave of economic activity around Arctic Dixon.

Such territorial reserves (Siberian taiga periphery) need some special forms of "light" 
non-industrial, expedition-type exploration with cross-country vehicles, ground effect machines, zeppelins, small aircrafts etc.

In his book published in $1961^{21}$, S.V. Slavin decisively associates the prospects of Siberia and the Soviet North with coal mining, hydropower facilities, development of non-ferrous metals deposits, wood and fish deposits. There were only several years left to oil production in Tyumen, but the book gives no hits on the forthcoming economic boom of Siberian hydrocarbons, the scale of which outshone all other mineral resources of Siberia.

But can we be sure that today, in the year 2017, we can foresee a surprise-like discovery of a new resource in Siberia that would turn our idea of its economic prospects upside down? Of course, we cannot. We need to be prepared for any surprise and understand that Siberian, spatially wide economy has always been driven by them.

But in any case, Siberia will always need mobile and effective delivery solutions as well as local energy supply systems. Just like before, the Soviet exploration of Siberia relied on the stationary base system and exploration tracks, the new exploration of Siberia will rely on the "light" vehicles not requiring and fundamental equipment and mobile energy supply machines.

In the last two decades, the Centre for the Northern and Arctic Economies of the Council for the Study of Productive Forces has developed some forecast documents (strategies, programmes, comprehensive plans) for a number of Siberian regions: Kemerovo Oblast, Altai Krai, Republic of Tuva, Republic of Buryatia, TransBaikal Krai, Evenkia (and also Siberian KhantyMansi and Yamalo-Nenets Autonomous Okrugs, Republic of Sakha - Yakutia, now included into the Ural and Far Eastern Federal Districts respectively).

All of them are facing the general challenge of innovative modernization of their economies, search for a new or improvement of the new specializations; they are searching for new way of positioning themselves on the global and national markets. For example, being an old industrial region, Kuzbass is condemned to a more social economic specialization due to the new industrial policy; it is also proven by the experience of the German Ruhr. The Altai Krai, the garner of Siberia, cannot maintain this pure status; it will obtain (and it is obtaining) a new industrial specialization in biopharmacology and biomedicine. The Trans-Baikal Krai is stepping aside from its military and security focus and arriving at an agricultural specialization for the Chinese market. The Republic of Sakha (Yakutia) is in the process of a structural manoeuvre from domination as a diamond extracting and producing facility to development of a new oil and gas facility. The mosaic on these regional processes also shapes up the new face of Siberia.

\section{Conclusion}

The endogenous economic development of Siberia under the influence of new theoretic ideas of economic growth, return increase, externalities based on diversity, means releasing the Siberian economic properties that used to be "got over" in the previous exploration model, fought against in order to be neutralized. The essence of the new exploration model is to transform its ultracontinental nature, corporativity and zonality from barriers into opportunities, into drivers of new economic growth. It is connected to the review of many previous phenomena and drivers of Siberian development:

- the vast territorial and industrial facilities, energy producing economic districts are now compact resource clusters and "small" economic districts;

- resource projects as the only sources of growth: now an important role in the gross regional product of Siberia is played by urban 
industry and urban services, as well as activities of large urban agglomerations of Siberia;

- large industrial facilities as the face of Siberian economy: now small and middle-sized businesses are gradually penetrating into all new branches of Siberian economy, including the sancta sanctorum, mineral deposits;

- deserted areas are not regarded as shamefully left out and subject to get involved into the economic turnover; the presence of reserve territories and deposits is a heritage preserved for the future generations;

- continuous linear ascension in economic development and exploration of Siberia is impossible; long pauses in exploration for "digestion" of the previously achieved results and concentration of innovations in some areas are efficient and substantiated;

- there is no monopoly value of the mineral, raw material, fuel and energy resources of Siberia; the value of water and agricultural resources oriented at the neighbouring Asian markets is growing;

- the EGP of Siberia should not be regarded as unconditionally disadvantageous and subject to overcoming with all possible economic techniques and efforts; the EGP of Siberia is multi-layered, and provides an opportunity of compensating disadvantages of one level with the advantages of another;

- modern tendencies do not need to be unconditionally extended into the middle-term future; Siberian economic history is rich in surprises that have often served as drivers for its new economic development, and we need to be prepared for them;

- production activity is not a key to creating a new economic space of Siberia; in the new era, innovations and novelties of all kinds are especially important for economic growth, and they require efficient personal communication, while Siberia has large problems due to the conservativeness and impromptness of the dominating means of communication, extremely slow flows of knowledge and updating of ideas;

- Siberian village is not the "periphery of periphery", condemned to drag behind the leading cities; in the colossal Siberian spaces, the village plays an unprecedented role in their outfitting in arrangement and has a history of entrepreneurial establishment and development. Due to these peculiarities, the villages are ready to play a more active role in the new cycle of exploration than they did before.

To resume the general postulates on the new exploration of Siberia, the main development guideline for Siberia is openness to experiments and innovative search, which now involves the main constructive effects of the arrangement of Siberian spaces, rejection of unified approaches and a brand new role of the state to encourage innovations of all kinds and get away from its former role of a simple lobbyist for large corporations, working in Siberia.

\footnotetext{
Geografiia Sibiri v nachale 21 veka: $v 6$ tomakh [Geography of Siberia in the early 21 $1^{\text {st }}$ century: in 6 volumes]. Executive editor V.M. Pliusnin. Institute of Geography of the Siberian Branch of Russian Academy of Sciences. Novosibirsk: Geo. 2014. Volume 1. Istoricheskaia geografiia [Historical geography]. Novosibirsk: Geo. 2014. 316 p. P. 8-9.

2 Like a fairy tale hero, this factor has the magical power to change the essence and nature of all economic phenomena and conditions, re-coloring and re-shaping them. For example, under the conditions of Siberian low-populated spaces, many kinds of economic activities, material assets, technical programs suddenly happen to be interpreted in a social context.

3 Bezrukov, L.A. (2008). Kontinental'no-okeanicheskaia dikhotomiia v mezhdunarodnom i regional'nom razvitii [Continental-oceanic dichotomy in international and regional development]. Novosibirsk. Geo Publishing House. 369 p.

$4 \quad$ Transport and transport fee determine the possibility of taking Siberian resources out, to the national and international markets. They are of no interest for anyone without the transportation options.

5 Siberia is an enormous overland enclave; for this reason all approaches to studying the specificity of enclave territories and their development, that have been suggested by world regional studies in the past decades, can be efficiently applied here, adjusted for its colossal size.

6 Term suggested by outstanding American economist Albert Hirschman.
} 
7 Geografia Sibiri v nachale 21 veka: $v 6$ tomakh [Geography of Siberia in the early 21st century: in 6 volumes] (2014). Executive editor V.M. Pliusnin. Institute of Geography of the Siberian Branch of Russian Academy of Sciences. Novosibirsk. Geo Publishing House. Volume 4. Prirodopol'zovanie [Nature use]; Executive editor L.A. Bezrukov, L.M. Korytnyy. 355 p.

8 Geografia Sibiri v nachale 21 veka: $v 6$ tomakh [Geography of Siberia in the early 21 $1^{\text {st }}$ century: in 6 volumes] (2014). Executive editor V.M. Pliusnin. Institute of Geography of the Siberian Branch of Russian Academy of Sciences. Novosibirsk. Geo Publishing House. Volume 1. Istoricheskaia geografiia [Historical Geography]. Novosibirsk. Geo Publishing House. 316 p. P. 186.

$9 \quad$ Pokshishevskiy, V.V. (1951). Zaselenie Sibiri [Populating Siberia]. Irkutsk. 208 p. P.26.

10 Blanutsa, V.I. (2015). Razvertyvanie informatsionno-kommunikatsionnoy seti kak geograficheskiy protsess (na primere stanovleniia setevoy struktury sibirskoy pochty) [Expansion of information and communication network as a geographic process (based on example of network structure of Siberian post)]. Thesis for the academic degree of a Doctor of Geography. Moscow: Institute of Geography of Russian Academy of Sciences. 350 p.

11 Granberg, A.G. (1983). Issledovanie ekonomicheskogo razvitiia Sibiri v razreze shirotnykh zon i mezoregionov [Research of the economic development of Siberia in the aspect of latitudinal zones and mesoregions]. In Publishing House of the Siberian Branch of the Academy of Science of the USSR. Social Science Series. № 1; 1. p. 8-19; Ekonomika Sibiri v razreze shirotnykh zon [Siberian economy in the aspect of latitudinal zoning] (1985). Collection of articles. Executive editor A. G. Granberg; Siberian Branch of the Academy of Sciences of the USSR, Institute of economy and industrial production management. Novosibirsk: Nauka, Siberian branch, 255 p.

12 Nekrasov, N.N. (1973). Problemy Sibirskogo kompleksa [Siberian complex problems]. Novosibirsk: West Siberian Book Publishing House. 222 p. P. 23.

13 Geografiia Sibiri v nachale 21 veka: $v 6$ tomakh [Geography of Siberia in the early 21 $1^{\text {st }}$ century: in 6 volumes] (2014). Executive editor V.M. Pliusnin. Institute of Geography of the Siberian Branch of Russian Academy of Sciences. Novosibirsk: Geo. Volume 4. Prirodopol'zovanie [Nature use] (2014). Executive editor L.A. Bezrukov, L.M. Korytnyy. 355 p. P. 179.

14 Piliasov, A.N., Kolesnikova, O.V. (2011). Otsenka tvorcheskogo potentsiala rossiyskikh regional'nykh soobshchestv. Novyy masshtab tvorcheskogo protsessa kak glavnoe otlichie postindustrial'noy i agroindustrial'noy transformatsii ekonomiki Rossii [Evaluating creative potential of Russian regional communities. New scale of creative process as the main distinctive feature of the postindustrial and agroindustrial transformation of Russian economy]. In Postindustrial'naia transformatsiia staropromyshlennykh rayonov Rossii [Postindustrial transformation of the old industrial districts of Russia]. Moscow. P. 226-310.

15 Nekrasov, N.N. (1973). Problemy Sibirskogo kompleksa [Siberian complex problems]. Novosibirsk: West Siberian Book Publishing House. 222 p. P. 33.

16 Pravitel'stvo Rossiyskoy Federatsii. Rasporiazhenie ot 5 iiulia 2010 goda № 1120-r «Ob utverzhdenii Strategii sotsial'no-ekonomicheskogo razvitiia Sibiri do 2020 goda» [Government of the Russian Federation. Order No. 1120-r of July 5, 2010 "On establishment of the Strategy of social and economic development of Siberia until the year 2020].

17 Piliasov, A.N. (2013). Kontury novoy teorii ekonomicheskogo rayonirovaniia Rossii (osnovnye elementy) [Contours of the new theory of Russian economic zoning (main elements)]. In Sovremennyye problemy regionalistiki [Current regional problems]. Proceedings of the International conference dedicated to the 110th anniversary of the Regional Economy and Nature Use department of Saint Petersburg State Economic University. Saint Petersburg: Saint Petersburg State Economic University Press.

18 Geografia Sibiri v nachale 21 veka: $v 6$ tomakh [Geography of Siberia in the early 21st century: in 6 volumes] (2014). Executive editor V.M. Pliusnin. Institute of Geography of the Siberian Branch of Russian Academy of Sciences. Novosibirsk: Geo. Volume 3. Khoziaystvo i naselenie [Economy and population] (2014). Executive editor N.M. Sysoeva, S.V. Riaschenko. 251 p. P. 72.

19 Nekrasov, N.N. (1973). Problemy Sibirskogo kompleksa [Siberian complex problems]. Novosibirsk: West Siberian Book Publishing House. 222 p. P. 128.

20 Syroechkovskiy, E.E., Rogacheva, E.V. (1999). Osobennosti prirody Sibiri i zapovednoe delo [Distinctive features of Siberian nature, reserve management and studies]. In Zapovedniki Sibiri [Nature reserves of Siberia]. Volume 1. Moscow: Logata. P. 8-17.

${ }_{21}$ Slavin, S.V. (1961). Promyshlennoe i transportnoe osvoenie severa SSSR [Industrial and transportation development of the Soviet North]. Moscow, Economic Literature Publishing House. 302 p.

\section{References}

Bezrukov, L.A. (2008). Kontinental'no-okeanicheskaia dikhotomiia $v$ mezhdunarodnom $i$ regional'nom razvitii [Continental and oceanic dichotomy in international and regional development]. Novosibirsk: Geo Academic Publishing House. 369 p.

Blanutsa, V.I. (2015). Razvertyvanie informatsionno-kommunikatsionnoy seti kak geograficheskiy protsess (na primere stanovleniia setevoy struktury sibirskoy pochty) [Expansion of information and communication network as a geographic process (based on example of network structure of Siberian post)]. Thesis for the academic degree of a Doctor of Geography. Moscow: Institute of Geography of Russian Academy of Sciences. 350 p. 
Geografia Sibiri v nachale 21 veka: $v 6$ tomakh [Geography of Siberia in the early $21^{\text {st }}$ century: in 6 volumes] (2014). Executive editor V.M. Pliusnin. Institute of Geography of the Siberian Branch of Russian Academy of Sciences. Novosibirsk: Geo. Volume 1. Istoricheskaia geografiia [Historical geography] (2014). Novosibirsk: Geo. 316 p. Volume 3. Khoziaystvo i naselenie [Economy and population] (2014). Executive editor N.M. Sysoeva, S.V. Riaschenko. 251 p. Volume 4. Prirodopol'zovanie [Nature use] (2014). Executive editor L.A. Bezrukov, L.M. Korytnyy. 355 p.

Granberg, A.G. (1983). Issledovanie ekonomicheskogo razvitiia Sibiri v razreze shirotnykh zon $i$ mezoregionov [Research of the economic development of Siberia in the aspect of latitudinal zones and mesoregions]. Publishing House of the Siberian Branch of the Academy of Science of the USSR. Social Science Series. № 1; 1. P. 8-19.

Gosudarstvenno-territorial'noe ustroystvo Rossii (ekonomicheskie $i$ pravovye osnovy) [Governmental and territorial arrangement of Russia (economic and legal basis)] (2003). Executive editor A.G. Granberg, V.V. Kistanov. Moscow: DEKA. 448 p.

Nekrasov, N.N. (1973). Problemy Sibirskogo kompleksa [Siberian complex problems]. Novosibirsk: West Siberian Book Publishing House. 222 p.

Pokshishevskiy, V.V. (1951). Zaselenie Sibiri [Populating Siberia]. Irkutsk. 208 p.

Piliasov, A.N., Kolesnikova, O.V. (2011). Otsenka tvorcheskogo potentsiala rossiyskikh regional'nykh soobshchestv. Novyy masshtab tvorcheskogo protsessa kak glavnoe otlichie postindustrial'noy i agroindustrial'noy transformatsii ekonomiki Rossii [Evaluating creative potential of Russian regional communities. New scale of creative process as the main distinctive feature of the postindustrial and agroindustrial transformation of Russian economy]. In Postindustrial'naia transformatsiia staropromyshlennykh rayonov Rossii [Postindustrial transformation of the old industrial districts of Russia]. Moscow. P. 226-310.

Piliasov, A.N. (2013). Kontury novoy teorii ekonomicheskogo rayonirovaniia Rossii (osnovnye elementy) [Contours of the new theory of Russian economic zoning (main elements)]. In Sovremennyye problemy regionalistiki [Current regional problems]. Proceedings of the International conference dedicated to the 110th anniversary of the Regional Economy and Nature Use department of Saint Petersburg State Economic University. Saint Petersburg: Saint Petersburg State Economic University Press.

Pravitel'stvo Rossiyskoy Federatsii. Rasporiazhenie ot 5 iiulia 2010 goda № 1120-r «Ob utverzhdenii Strategii sotsial'no-ekonomicheskogo razvitiia Sibiri do 2020 goda» [Government of the Russian Federation. Order No. 1120-r of July 5, 2010 "On establishment of the Strategy of social and economic development of Siberia until the year 2020].

Slavin, S.V. (1961). Promyshlennoe i transportnoe osvoenie severa SSSR [Industrial and transportation development of the Soviet North]. Moscow, Economic Literature Publishing House. $302 \mathrm{p}$.

Syroechkovskiy, E.E., Rogacheva, E.V. (1999). Osobennosti prirody Sibiri i zapovednoe delo [Distinctive features of Siberian nature, reserve management and studies]. In Zapovedniki Sibiri [Nature reserves of Siberia]. Volume 1. Moscow: Logata. P. 8-17.

Ekonomika Sibiri v razreze shirotnykh zon [Siberian economy in the aspect of latitudinal zoning] (1985). Collection of articles. Executive editor A.G. Granberg; Siberian Branch of the Academy of Sciences of the USSR, Institute of economy and industrial production management. Novosibirsk: Nauka, Siberian branch, 255 p. 


\title{
Сибирь: поиски новой модели развития
}

\author{
А.Н. Пилясов \\ Центр экономики Севера и Арктики \\ АНО «Институт регионального консалтинга» \\ Россия, 117342, Москва, ул. Бутлерова, 176
}

Ни для одного другого крупного макрорегиона России неотложность поиска новой модели развития не стоит так неотложно, так императивно, как для Сибири. Будучи лидером в стране и мире по природным богатствам, водным ресурсам, эта кладовая природных ресурсов по уровню и качеству жизни проигрывает многим федеральным округам. Сибирь стремительно утрачивает свои позиции и по ключевым экономическим индикаторам. Общие контуры нового освоения Сибири - это открытость на эксперимент и инновачионный поиск, с которым теперь связаны основные конструктивные эффекты обустройства сибирских пространств, отказ от унифииированных подходов и абсолютно новая роль государства, которое поощряет новшества всех видов и уходит от своей прежней роли простого лоббиста крупных корпораиий, работающих в Сибири.

Контуры новой модели развития Сибири должны учитывать следующие факты:

1. Самыми рентабельными в Сибири являются не добычные, а обрабатывающие производства, менее чувствительные к чертам ультраконтинентальности и удаленности сибирской экономики. Гибридность, смесовый характер новых сибирских месторождений во многих случаях обусловливает оправданность и целесообразность совмещения мест их добычи и переработки.

2. Возвращение на время назад всегда было очень характерно для хозяйственного освоения сибирских пространств: сначала быстрый прорыв к новому, потом задержка, пауза, а на самом деле усвоение и закрепление новшества в пространствах Сибири, потом новое движение.

3. В периоды активного освоения Сибири доминировала широтная коммуникация по трассам и широтным транспортным каналам, а в периоды пауз в освоении (сжатия освоенности) «естественная» (физико-географическая) коммуникация по каналам (бассейнам) великих сибирских рек.

4. Сибирь имеет замыкаютие позищии среди федеральных округов по быстрым средствами коммуникации, что означает абсолютную информационную периферийность, очень медленный обмен идеями и, как следствие, значительную интеллектуальную консервативность. Должны быть предприняты специальные усилия, именно для Сибири, которые обеспечат ее существенно большую включенность в национальные и международные информационные обмены, чем сегодня.

5. Сибирское село и по показателям фермерской активности, и по уровню сельской телефонизачии оказывается сравнительно лучше подготовленным к усвоению новшеств, к обновлению модели экономического развития, чем среднестатистическое российское село, чем села других федеральных округов.

6. Сравнительная роль крупных сибирских городов в развитии Сибири безусловно выме, чем роль городских агломераций в других федеральных округах - именно в силу низкой плотности и слабой обустроенности сибирских пространств. Сибирская урбанизачия в отличие от районов центра захватывает пространство не целиком, а прерывистым, выборочно-сплошным образом, через сеть форпостных и локальных баз освоения, которые осуществляют контроль местного, районного или более обширного регионального пространства.

7. Подобно тому, как в компактных креативных регионах иентральной России аккумулируются творческие люди со всей страны, в городах-иентрах общирных территорий Сибири кониентрируются предприимчивые таланты со всего колоссального регионального пространства. Особая сибирская модель креативности еще раз подтверждает, что в Сибири трудно рассчитывать на успех модели Силиконовой долины, основанной на значительной плотности 
и плотной коммуникации каждого с каждым. Здесь будут формироваться другие модели инновационного процесса, которые конструктивно используют факторы изолированности и периферийности обширных сибирских пространств.

8. Идея возрастающей отдачи означает на сибирских пространствах получение эффектов от крупных и очень рассредоточенно расположенных городских агломерации; низовых экономических районов, формирующих локализованные площадки местных хозяйственных кластеров; контактных территорий сибирского российско-китайского приграничья. Все эти эффекть задействуют силь малого и среднего предпринимательства, которое генерирует их, активно взаимодействуя друг с другом и крупнылми ресурсныли компаниями Сибири.

9. Как раньше советское освоение Сибири опиралось на систему стационарных баз и трасс освоения, так новое освоение Сибири будет опираться на «легкие», не требующче фундаментального обустройства, транспортные средства и мобильные средства энергообеспечения.

Ключевые слова: Сибирь, новая модель освоения, инновационное развитие, возрастающая отдача.

Научная специильность: 08.00.00 - экономические науки. 